\title{
SOCIOLINGUISTIC RATIONALE FOR THE USE OF PODCASTS IN ONLINE COMMUNICATIVE LANGUAGE TEACHING
}

\begin{abstract}
Summary. The article is devoted to highlighting peculiarities of podcasts, namely their sociolinguistic importance in terms of communicative language teaching. In the course of this article a notion of sociolinguistic competence (SLC) has been thoroughly reviewed. The division of podcasts has been derived on the basis of definitions provided by G. Stanely, S. Jain, and F. Hashmi. Such elements of SLC as understanding speakers from various cultural environments, genuine usage of the language and its elements in diverse cultural settings, and the acceptance of equality of register variations have been examined through the prism of communicative language teaching method. Furthermore, the benefits of podcasts such as novelty, variability of themes, length, and levels of language in terms of CLT have been analyzed via two podcasts.
\end{abstract}

Keywords: sociolinguistic competence, communicative language teaching, podcasts, audio- and video- materials.

Козуб Р.O.

Львівський національний університет імені Івана Франка

\section{СОЦІОЛІНГВІСТИЧНІ ПЕРЕВАГИ ПОДКАСТІВ У ПРОЦЕСІ КОМУНІКАТИВНОГО НАВЧАННЯ МОВИ ОНЛАЙН}

\begin{abstract}
Анотація. У статті проаналізовано важливість здобуття соціолінгвістичної компетенції під час вивчення іноземної мови. Адже вона забезпечуе здатність доречного вживання мови та мовних конструкцій задля успішного спілкування з представниками інших культур та носіями мови. Соціолінгвістична компетенція також включає розуміння та доречне застосування мови у певних соціальних контекстах. Ï̈̈ вивчення поеднуеться з комунікативним методом, оскільки йому характерні наголоси на здобутті комунікативної компетенції завдяки розвитку мовних навичок з мінімальним використанням підручників. Використання подкастів у процесі вивчення іноземних мов $е$ доречним, через те що вони відповідають зазначеним критеріям комунікативного методу. Перевагами подкастів е їх тематична різноманітність, різна тривалість, та простота використання. Подкасти е різних видів, тому їх класифікують за цільовою аудиторіею - автентичні, учнівські, педагогічні; та за мовними аспектами - подкасти оріентовані на сприйняття мови, розмови носіїв, вивчення ідіоматичних виразів і лексики. У статті розглянуто соціологічні особливості подкасту "Smombie", де увага зосереджена на вивченні нової лексики, а також на подкасті "Karl Pikington: A day in the life", де один з мовців е носіям естуарної англійської. Подкасти е не менш важливими з перспективи соціолінгвістики, оскільки вони є джерелом сучасної мови з їі різновидами та особливостями. У цьому дослідженні розглянуто аспекти самопрезентації під час комунікації та наголошено на важливості соціолінгвістичної свідомості у процесі комунікативного вивчення іноземної мови. Подкасти, серед засобів аудіо- та відео- матеріалів, є перспективними елементами для дослідження та вивчення мови. На підставі зробленого нами дослідження можна зробити висновок про те, що застосування подкастів вдосконалюе навики аудіювання, ознайомлюе з лексичним матеріалом, мотивуе та зацікавлюе вивчати і практично застосовувати мовні кліше та ін. Отже, подкасти можна використовувати як домінуючий чи допоміжний засіб навчання іноземної мови, адже вони передбачають: дискусії, роботу в групах та парах, інтерактивні презентації матеріалу, практичне спілкування, обговорення заданої теми та орієнтованість на розвиток соціолінгвістичної компетентності.
\end{abstract}

Ключові слова: соціолінгвістична компетенція, комунікативний метод вивчення мови, подкасти, аудіота відео- матеріали.

Problem statement. In the 21st century, we live in a society where connection with almost every location of the world is possible. The spread of English as the lingua franca of international business and politics highlighted the need of specialized communication where carrying the information in an effective and productive way is of great importance. That is why not only the method of studying but the aspects, especially -the sociolinguistic competence is becoming more significant [4, p. 540]. Within the current situation in the world, the necessity of online teaching has intensified. This demand has led to analyze methods and approaches to teaching English as a foreign language in a different manner. This article is concentrated on the problem of gaining sociolinguistic competence via incorporating audio- and video- materials, namely podcasts, into the lesson.
Recent research and publications. The gist of parole differentiations in various social settings and explaining it, dwelling into the style of using language in specific relationships in a community and analyzing the manner of conveying information are the things to be particularly important to sociolinguists.

Thus, the subsequent matter lies in defining the term sociolinguistics. Having analyzed the definitions provided by J. Gumperz, J. Cook-Gumperz, and J. Holmes, the main elements of sociolinguistics are as follows: social and cultural contexts, conveying social meaning, society's effect on the language, and its social functions. Hence, the proper usage of these elements can be distinguished as sociolinguistic competence.

Furthermore, sociolinguistic competence has established to be one of essentials in terms of scrutiniz- 
ing the communication skills in the contemporary world. For that reason a number of definitions of the term "sociolinguistic competence" (further in the article SLC) should be considered. J. Holmes views SLC as "The knowledge which underlies people's ability to use language appropriately" [5, p. 440]. R. Bayley states that SLC is defined as "Successful communication, whether within a culture and between persons of different cultures, requires an understanding of the meaning of speech acts within a community as well as the ability to interpret the meaning of speakers' uses of different linguistic forms, many of which are variable" [2, p. 8]. V. Bagaric and J. Mihaljevic Djugnovic claim that "Sociolinguistic competence refers to possession of knowledge and skills for appropriate language use in a social context" [2, p. 99].

We have taken our research further and developed the main features of a sociolinguistically competent speaker. They are as follows: understanding of the speakers from other cultural backgrounds, the proper usage of the language in different cultural settings, and the acceptance of equality of register variations.

The notion of "communicative competence" should be looked upon in the context of the CLT. This term was introduced by D. Hymes, the establisher of the ethnography of communication, on the contrary to N. Chomsky's notion "linguistic competence". Consequently, communicative competence is the ability to use properly grammatical knowledge of the language and accordingly integrate social knowledge during discourse. Hereinafter this definition was supplemented by four main components of communicative competence. According to the theory by M. Canale and M. Swain, they are as follows: 1) grammatical or linguistic competence (capability of using accurate grammatical constructions and to build appropriate sentences); 2) sociolinguistic competence (relevant application of vocabulary, register, politeness, and style in a certain sociocultural context); 3) discourse competence (ability to combine language structures into cohesive and coherent texts of various styles); 4) strategic competence (consecutive usage of verbal and non-verbal strategies during the process of communication) [3].

The privileges of CLT are prioritizing the communicative dimension of the language, providing motivation within the classroom, emphasizing on the interests and needs of the learner. In accordance with CLT, there is no need to use certain textbook since it does not enhance the principal outcome of this method which is the ability to develop proper verbal skills and communicate effectively in the target language.

Nevertheless, several linguists (such as M. Swan, E. Ridge, and S. Bax) decry CLT for deficiency of the system and structure in the process of learning, in view of the fact that it is concentrated mostly on everyday functional aspects of the speech and therefore encounter insufficient usage of formal aspects of the language.

Without being affected by the aforementioned opinions, it can be stated that with the help of interactive methods of teaching English, which are currently among the trends, sociolinguistic competence can be easily integrated in the process of studying.
The novelty of this work lies in an attempt to devise a model of SL competence which would incorporate audio- and video-materials as a part of communicative language teaching online with the intention of enhancing sociolinguistic awareness of students.

The purpose of the research is to outline sociolinguistic features of podcasts in the process of communicative language teaching online.

Presentation of the main material. Interaction is one of the most basic exigencies. No wonder people are looking for the ways to socialize, express their point of view, and reach the consensus with others. Language shapes the manner we think and establishes what society can think about, no wonder that in the era of technologies people view these SN websites (Instagram, Twitter, YouTube, and Facebook) as an influential tool on the community, as a business platform, and as a source of the language to be learned and analyzed. The language varieties can be perfectly traced with their help. The differences in register, dialects, and accents can be learnt and practiced while listening to podcasts [4].

A word "podcast" is derived from the mixture of "ipod" and "broadcast". Podcasts are the audio blogs or shows which are published in the network. Usually they are published in the arrangements devoted to certain objectives or subject matters. Podcasts are mostly of free access and downloadable (in the favorable for the listener time) either on a portable mp3 player or any other type of gadgets (including personal computers and smartphones). Podcasts are considered to be a rather effective way of forming the communicative competence in the process of studying within the CLTM. Moreover, they do not require extensively multitudinous tools to be listened at the lesson. The loudspeaker and a mobile phone is enough to conduct the class which is convenient for the current setting at the different levels of education.

We have taken the division of G. Stanely in his article "Podcasting for ELT" three main categories - authentic podcasts, teacher podcasts and student podcasts, defined them and filled in with the most relevant examples for each category [8].

Authentic podcasts are not aimed at teaching ESL. They are mostly suitable for the students with the higher level of English. Moreover, they are principally longer and thus require certain time to listen, analyze and discuss afterwards. The examples of authentic podcasts are "The Melissa Ambrosini Show", "99\% Invisible", "The Dollpop" and "The Secret History of Hollywood".

Teacher podcasts are created as the methodical supply for the teacher. They contain methodical recommendations and pedagogical techniques created for beneficial perception of insights (mainly from the podcasts) in the process of studying. The examples of such podcasts are "TeacherCast", "Teacher Aid", "It's all elementary".

Student podcasts are created as the means of studying. Their key features are simplified language and short duration (10 minutes on average). With their help learners can improve their listening skills, revise certain material both lexical and grammatical, raise the level of motivation and engagement in learning English, determine and apply different language clichés, etc. The most prev- 
alent student podcasts are "BBC: the English We Speak", "Spark", "Brains on" and "The Real Life English Podcast".

S. Jain and F. Hashmi provide the succeeding division of student podcasts [7, p. 159]:

1) Podcasts based on comprehension activities, interviews and vocabulary ("Happy English Podcast").

2) Podcasts based on idiomatic expressions with their usages ("The English we speak").

3) Podcasts containing conversations between the native speakers ("1-minute English").

4) Podcasts based on encouraging careful listening by the listeners ("Culips").

5) Accompanied by the text or the lyrics ("Luke's English podcast").

6) Podcasts containing vocabulary with their pronunciation ("Espresso English").

7) Story-based podcasts followed by listening comprehension questions ("Culips").

Selection of podcasts is mainly established by the teacher. In terms of the CLTM, a podcast may be chosen on the basis of D. Hymes's notion of communicative competence and his model of speaking. [6] Podcasts have a number of advantages for teachers since they are of any length and theme, they do not require any special equipment, and often they already have a typescript written or exercises included which is unequivocally comfortable for the teacher.

We have chosen two podcasts to highlight their sociolinguistic advantages in the process of CLT. A podcast "The English We Speak" pertains to student podcasts in G. Stanley's classification. Concerning S. Jain and F. Hashmi's division, it is a sample of podcasts based on idiomatic expressions with their usages. "The English We Speak" is concentrated on sociolinguistic competence thus it consists of the learning, discussing and practicing of vocabulary. The recordings are segregated into certain topics such as phrasal verbs, idioms, and neologisms. The average length of an episode is about 2 minutes which makes it suitable for classroom lessons. "The English We Speak" is accessible on the website of BBC learning podcasts (The English We Speak, 2018) and for devices that run on IOS or Android operating systems it is available on the application "Stitcher".

The episode "Smombie" (number 1804-02) is oriented on learners with the intermediate level of English. Referring to the model of speaking by D. Hymes, the speech act in "Smombie" is set between native speakers in an informal surrounding. The goal is to introduce a new word "smombie" to the learners. The tone and the spirit of the talk are informal and positive. The speech act is fairly expressive and therefore exclamations "argh", "ouch" are not only suitable, but they establish the manner of communication. The episode is divided into four parts: 1) general introduction, 2) highlighting and explaining the new word, 3) the examples of practical use, 4) closing.

The following podcast to be reviewed is titled "Karl Pikington: A day in the life". Ricky Gervais, an English stand-up comedian, actor, screenwriter, director, producer, musician, and TV presenter, is an author of these series. He speaks English with an Estuary accent. Accordingly, listening to an authentic podcast with the accent without any preparation might be onerous. Whilst with specific groundwork, predominantly concerning differences in the register, it is possible for students to practice their accent comprehension not only during the lesson, but afterwards, at a personalized tempo. The fundamental features are: emphasizing on spelling variations, understanding salient aspects of the talk, and mastering vocabulary. As an additional instrument for illustrating the Estuary accent, a teacher video "How to Do an Estuary Accent । Accent Training" by voice and speech coach Andrea Caban can be presented to students. It covers rudimentary features of Estuary English as its sociocultural background, differences from RP, and the examples of usage.

Podcasts are gaining popularity as the means of the CLTM since they are suitable for introducing new vocabulary, starting a discussion of opinions, practicing listening comprehension and improving accent in the ESL classroom. They are equally valuable from the perspective of SLC for they are the source of contemporary language with its up-todate variations and vocabulary items.

Conclusions. This article leads to assessment of the importance of sociolinguistic competence in terms of CLT. We have analyzed the main elements of sociolinguistics (social and cultural contexts, conveying social meaning, society`s effect on the language, and its social functions) in this article. It has been substantiated that sociolinguistic competence is one of important kernels in terms of researching the communication skills. This work is focused on podcasts for their predominance as the means of the CLTM since they are suitable for introducing new vocabulary, starting a discussion of opinions, practicing listening comprehension, and improving accent in the ESL classroom. Podcasts are equally valuable from the perspective of SLC considering they are the source of contemporary language with its up-to-date variations and vocabulary items. This research gave us gleanings on self-presentation in discourse and demonstrated that the application of sociolinguistic awareness, in particular, audioand video-materials, to the study of communicative language teaching provides means for a thorough study of its methods within a new perspective. The results, however, are far from conclusive and open up opportunities for further research.

\section{References:}

1. Bagarić, V. (2007). Defining Communicative Competence. Zagreb: Metodika. Review paper. 8th ed., pp. 94-103.

2. Bayley, R. (2005). Second Language Acquisition and Sociolinguistic Variation. Intercultural Communication Studies. Pp. 1-13.

3. Canale, M. (1980). Theoretical Bases of Communicative Approaches to Second Language Teaching and Testing. Oxford: University Press, pp. 1-47.

4. Gumperz, J., \& Cook-Gumperz, J. (2008). Studying language, culture, and society: Sociolinguistics or linguistic anthropology? Journal of Sociolinguistics, vol. 12(4), pp. 532-545. Retrieved from: https://onlinelibrary.wiley.com/ doi/abs/10.1111/j.1467-9841.2008.00378.x 
5. Holmes, J. (2013). An Introduction to Sociolinguistics. New York: Routledge. Retrieved from: https://onlinelibrary. wiley.com/doi/abs/10.1111/j.1467-9841.2008.00378.x

6. Hymes, D. (2001). Foundations in Sociolinguistics: An Ethnographic Approach. London: Routledge.

7. Seema, J. (2013). Advantages of Podcasts in English Language Classroom. Journal of Indian Research, vol. 2, pp. $158-163$.

8. Stanely, G. (2006). Podcasting for ELT. Retrieved from: https://www.teachingenglish.org.uk/article/podcasting-elt

9. The English We Speak. (2018). Retrieved from: http://www.bbc.co.uk/learningenglish/english/features/theenglish-we-speak/ep-180402

10. The Ricky Gervais Show (2019). Retrieved from: https://www.therickygervaisshow.com/podcasts/karl-pilkingtona-day-in-the-life

\section{Список літератури:}

1. Bagarić V. Defining Communicative Competence / V. Bagarić, J. Mihaljević Djigunović // Metodika. Review paper. Zagreb. 2007. № 8. P. 94-103.

2. Bayley R. Second Language Acquisition and Sociolinguistic Variation / Robert Bayley // Intercultural Communication Studies. 2005. P. 1-13.

3. Canale M. Theoretical Bases of Communicative Approaches to Second Language Teaching and Testing / M. Canale, M. Swain. Oxford University Press. 1980. P. 1-47.

4. Gumperz J. Studying language, culture, and society: Sociolinguistics or linguistic anthropology? / J. Gumperz, J. Cook-Gumperz. Journal of Sociolinguistics. 2008. № 12. P. 532-545. URL: https://onlinelibrary.wiley.com/doi/ abs/10.1111/j.1467-9841.2008.00378.x

5. Holmes J. An Introduction to Sociolinguistics / Janet Holmes. New York: Routledge, 2013. 490 p. (4).

6. Hymes D. Foundations in Sociolinguistics: An Ethnographic Approach / Hymes. London : Routledge, 2001.249 p.

7. Seema J. Advantages of Podcasts in English Language Classroom / J. Seema, H. Farha. Journal of Indian Research. 2013. № 2. P. 158-163.

8. Stanely G. Podcasting for ELT. Stanely. 2006. URL: https://www.teachingenglish.org.uk/article/podcasting-elt

9. The English We Speak. 2018. URL: http://www.bbc.co.uk/learningenglish/english/features/the-english-we-speak/ ep-180402

10. The Ricky Gervais Show. 2019. URL: https://www.therickygervaisshow.com/podcasts/karl-pilkington-a-day-in-the-life 